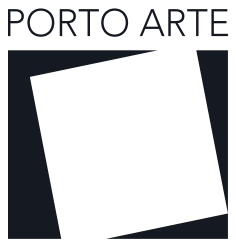

Revista de Artes Visuais

v. 24 ก. 42

nov/dez 2019

e-ISSN:2179-8001

VERSÃO

Maraliz de Castro Vieira Christo ${ }^{1}$

\title{
Afrodescendant memory in Brazilian museums: the case of the Mariano Procópio Museum²
}

A memória afrodescendente nos museus brasileiros: o caso do Museu Mariano Procópio

\begin{abstract}
The Mariano Procópio Museum originated from a private collection, formed between the 19th and 20th centuries, by Alfredo Ferreira Lage, and donated by him to the city of Juiz de Fora. By identifying representations of African descendence in the collection, we question its origin. They can be grouped into three categories: those acquired by the institution, reinforcing a conservative discourse; those donated by the artists themselves spreading their works; and, most of them, those who received the City's acquisitive prize, when exhibited at the Salon of the Society of Fine Arts Antonio Parreiras, from 1950 to 1980, and were allocated in the museum, breaking old canons.
\end{abstract}

Keywords

African descent memory. Mariano Procopio Museum.

Resumo

o Museu Mariano Procópio originou-se de uma coleção particular, formada entre os séculos XIX e XX, por Alfredo Ferreira Lage, e doada por este ao município de Juiz de Fora. Ao identificarmos representações de afrodescendentes no acervo, nos interrogamos sobre sua procedência. Pode-se agrupá-las em três categorias: as adquiridas pela instituição, reforçando um discurso conservador; aquelas doadas pelos próprios artistas difundindo seus trabalhos; e, a maioria, as que receberam o prêmio aquisitivo da prefeitura, quando expostas no Salão da Sociedade de Belas Artes Antônio Parreiras, entre os anos de 1950 a 1980, e foram alocadas no museu, rompendo antigos cânones.

Keywords Palavras-chave

Memória afrodescendente. Museu Mariano Procópio.

1- Universidade Federal de Juiz de

Fora, Brasi ORCID: 0000-0002-8957-0645

2- Text received ono: $25 /$ july/2019 Texto published in: 23/dez/2019 


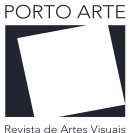

VERSÃO

1- We thank Eduardo de Paula Machado (Dudu), an employee of the Mariano Procópio Museum, for his assistance in surveying the works. We emphasize the difficulty of sometimes identifying a person as being of African descent.

2- May 131888 Commemorative Statuette. Anonymous. Silver and marble, $75 \mathrm{~cm}$., MMP

3-Preciousness of the Bastos Dias collection ". Mercantile Diary,

Juiz de Fora, p. 1, 20 jun. 1929

4- GOMES, Lindolfo. Monumento à princesa Isabel. Diário Mercantil, Juiz de Fora, p. 2, 01 jul. 1934 (PINTO, 2008, p. 248)

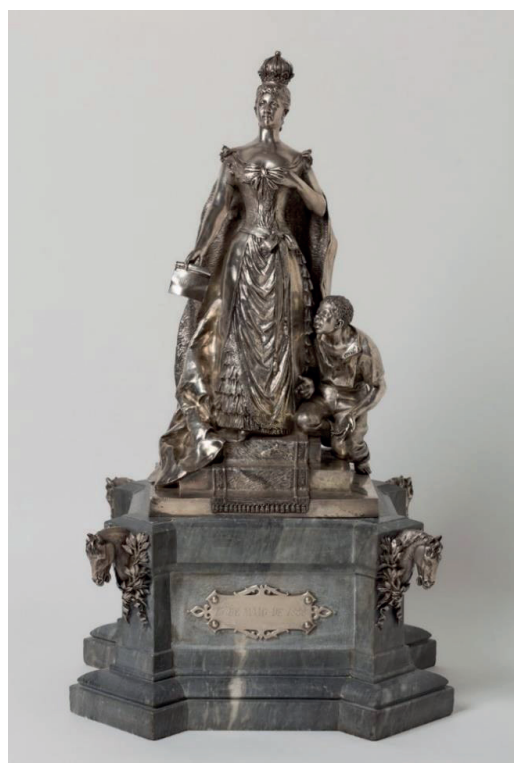

Figure 1. Anonymous, May 13 1888 Commemorative Statuette, s / d. Silver and marble, $75 \mathrm{~cm}$. MMP (Reproduction Mariano Procópio Museum)
The Mariano Procópio Museum originated from a private collection, formed between the 19th and 20th centuries, by Alfredo Ferreira Lage, and donated by him to the municipality of Juiz de Fora in 1936. The eclectic character of the collection, common in the period, allowed the museum to present features of a historical, decorative arts and fine arts museum. Alfredo Ferreira Lage's collection was formed largely from trips to Europe, by purchase, mainly at auctions, as well as donations from friends and artists.

By identifying representations of African descent or themes related to their culture in the collection, some in stark contrast to the collection as a whole, we begin to wonder about their origin and meaning. ${ }^{1}$

\section{Works Acquired By First Directors}

\subsection{Alfredo Ferreira Lage: The Former Slave At The Feet Of The Redement Princess.}

From the time of his father, Mariano Procopio Ferreira Lage, Alfredo's family maintained a long friendship with the imperial family, even after the Proclamation of the Republic. Alfredo became a royalist, acquiring many pieces related to the Empire, such as D. Pedro II's coronation clothes, portraits of the imperial family, Quinta da Boa Vista furniture and a multitude of objects, prints, photos and documents. It was an effort also developed by other collectors to preserve the memory of the monarchy.

Among the pieces we highlight a silver ${ }^{2}$ statuette, representing Princess Isabel, with cloak and crown, in reference to the third kingdom, which was thought to be close. She holds in her right hand a possible parchment that reads "May 13" in reference to the Golden Law and, on her left, on her knees, a black man. The statuette has silver horse-head angles at the base of the marble, probably a tribute from the Jockey Club of Brazil to the princess, still in 1888. The statuette was acquired by Alfredo Ferreira Lage, in the auction of a lot of Bernardino Bastos Dias collection, in 1929, where were several pieces related to the Empire. ${ }^{3}$

The statuette presents the black man on his knees in a pose of worship, reinforcing a recurring iconography in the representations of Princess Isabel as redeemer. However, the former slave does not appear with his naked torso and broken shackles, as has become common. He wears a shirt, little hint of his new social situation, although he is still half open and the man remains barefoot (DAIBERT JR., 2014)

The representation proposed by the statuette will be reiterated in the monument to Princess Isabel erected in the museum gardens in 1934. To make its construction possible, a specific commission was formed, chaired by Alfredo, responsible for organizing various activities involving the city in obtaining the funds needed: ten contos de réis. The execution of the monument was by sculptor Humberto Cozzo (1900-1981), who did not charge for his work. ${ }^{4}$ 
At three and a half meters high, the monument was made from an Art Deco-style white granite base of Petrópolis, with a bronze medallion in the front, with the effigy of Princess Isabel in low relief. Just below, a sign reading: "Princeza Izabel, the people of Juiz de Fora"; and practically to the ground, also in low relief, the traditional image of a life-size former slave on his knees, practically naked, with broken chains on his wrists, arms, and gaze raised toward the princess.

Both the acquisition of this statuette and the construction of the monument in the park in honor of Princess Isabel remain in Alfredo's actions to preserve the memory of the monarchy.

The insertion of African descendants in the narratives of historical museums until recently was mostly only at the time of abolition, as a witness of the princess's benevolence and not of her own struggle.

Interesting to note the museum's existence of a collection of slave torture instruments. Significantly, these instruments were not purchased by Alfredo Ferreira Lage, but donated in 1941 by Henrique Surerus (1860-1948) (PINTO, 2008, p. 346), industrialist, member of the Mariano Procópio Museum Friends Council. ${ }^{5}$

In the 1980s, there was an expansion of the exhibition space, organizing the historical pieces chronologically. The objects of torture were presented in the last room dedicated to the Empire, arranged on a wooden base, placed on the floor. Above them, a drawing by Princess Isabel ${ }^{6}$ was fixed to the wall: a mirrored copy of the print "Rosto de Mulher", Cours élémentaire, lithographed by Julien and printed by François Delarue in Paris, produced from a Constant Joseph Brochart's work (1816-1899). The design was acquired by Alfredo Ferreira Lage from the estate of Joaquina de Oliveira de Araújo Gomes, Baroness of São Joaquim, who died in 19297. Despite the existence of caption, identifying it as authored by Princess Isabel, the general public came to perceive it as a portrait representing the princess herself. The wooden base with the torment instruments had become a votive altar to the princess, seen as saint in the alleged portrait, with a crucifix around her neck. Next to the drawing was the figurine representing the Imperial Princess and the former slave. Museography suppressed the critical potential of torture instruments, submitting them to the discourse of Princess Isabel as redeemer (CHRISTO, 2014, p. 55-68).

\subsection{Geralda Armond: The Priest And The Coup Of 1964}

After Alfredo Ferreira Lave's death in 1944, his cousin, Geralda Armond Ferreira Marques (1913-1980), will take over the direction of the Mariano Procópio Museum. If Alfredo invested in preserving the memory of the Empire, Geralda will engage in the fight against the proclaimed Communist threat and in the construction of the 1964 Coup memory. Geralda Armond acted as a poet, wrote for the Diário Mercantil, actively participated in various cultural and philanthropic activities. , in defense of good manners. It will be among the "brave guardians of home and country", that is, the women of Juiz de Fora who participated in the "Women's Campaign for Democracy" (CAMDE) and supported the military coup. ${ }^{8}$
5- It belongs to the Surerus collection, another donated work, a feminine nude, signed by Gerhardt Kappel, titled Cabocla, dated 1945 . Oil on canvas, $23 x$ $16 \mathrm{~cm}$.

6- Princess Isabel, Portrait, October 15, 1863. Drawing, mixed technique, paper, crayon, graphite and colored pencil, $42 \mathrm{x}$ $52 \mathrm{~cm}$., MMP.

7- See listing of 1944, folio 9, verse: " 1 drawing by Princess Isabel, 1863. Acquired from the estate of the Baroness of St. Joachim".

8- Organization originally created in Rio de Janeiro to protect the homeland and family from communism. (ROSE, 2009) 


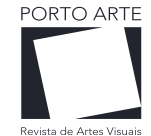

VERSÃO
9- In fact he would be 45 years old $(08 / 10 / 1920-23 / 04 / 04)$

10- Apparently he was not part of FEB.

11- Diário de Notícias, Rio de Janeiro, 24/04/1965.
Geralda Armond created, in the museum, a room dedicated to General Olímpio Mourão Filho (1900-1972), responsible for the deployment of troops from Juiz de Fora to Rio de Janeiro, at dawn on March 30, 1964, precipitating the coup that deposed the President João Goulart.

Inaugurated on March 31, 1966, the room displayed objects, books, documents and photographs on the subject. On the anniversary of the "Democratic Revolution" in 1970, in a solemn event, the general himself donated some personal effects, including his sword. After the museum reorganization in the 1980 s, the room was deactivated.

Besides General Olímpio Mourão Filho, another figure linked to him will be present in the museum's collection. We refer to the portrait of Father Wilson Valle da Costa (1920-1965), an African descent.

Chaplain and captain of the Fourth Military Region, born in Juiz de Fora, Father Wilson gained notoriety when he participated in the first United Nations (UN) international peace mission in 1957. Upon his return, he became an influential communicator responsible for "Ave Maria" prayer and for the "Problems of life" program on the now defunct radio PRB-3, the local station of the Associated Diaries Group. Reaching high ratings, he defended with humor and simple language conservative and anti-communist positions (COSTA, 2003). At her death on April 23, 1965, the Daily News announced this:

"MORREU O CAPELÃO VALE COSTA. Vitimado por uma endocardite, resultante da extração de um dente, faleceu, ontem, com 42 anos $^{9}$, o padre Wilson do Vale Costa, capelão da Quarta Região Militar e colaborador do general Mourão Filho na articulação do movimento revolucionário, em Juiz de Fora.(...)

HOMENAGENS. O capelão, também capitão do Exército, era herói da $\mathrm{FEB}^{10}$, e teve atuação destacada na resistência às articulações dos comunistas, em Juiz de Fora, quando o ex-governador Miguel Arrais visitou a cidade."11

As the newspaper Diário de Notícias said, Father Wilson was a collaborator and friend of General Olímpio Mourão Filho. He appears in some photographs after the coup alongside the General. The chaplain captain did not experience the lead years of the military dictatorship, as he fell ill in 1964 and died in October 1965. For his funeral, the general came to Juiz de Fora and drove the army car that took the body to his last address (COSTA, 2003, p. 187). It is interesting to note that Wilson was portrayed in his military uniform and not in cassock, making it clear which memory should be privileged. 
Father Wilson entered political life, being Secretary of Education and Culture of Mayor Olavo Costa (1959-1962) of the Social Democratic Party (PSD), in his second term. His action focused on obtaining scholarships for many who sought him. He tried to apply for the succession of Olavo Costa in the city hall, but was prevented by the Church.

As Secretary of Education and Culture, he had direct contact with Geralda Armond, with the museum reporting to his secretary. But regardless, they often found themselves in activities promoted by CAMDE, in the struggle against communism. According to Joanice Gonçalves da Costa:

Três pessoas se destacaram na preparação ideológica, na criação de uma mentalidade anticomunista na cidade: a poetisa Geralda Armond Ferreira Marques, diretora do Museu Mariano Procópio; Padre Wilson Valle da Costa, um conhecido capelão militar e apresentador de um programa radiofônico e, como figura de apoio, o arcebispo Dom Geraldo Maria de Moraes Penido. Estas pessoas se destacaram pelo seu notório reconhecimento público e, consequentemente pela sua capacidade de convencimento das massas, principalmente por utilizar símbolos próprios do catolicismo no discurso político (COSTA, 2004, p. 99).

We do not know when and how the painting became part of the museum's collection, but it would be in line with the memory received by the institution.

The portrait of Father Wilson could be displayed in the Sala de Juiz de Fora, inaugurated by Geralda Armond, during the centenary of the city, in 1950. The painting was painted by Djanira de Almeida Diniz, knowing only to have taught painting (Três amigos pintores, 2012) and participated in some local artistic events $^{12}$. In 1967, in the annual report of his management, Geralda Armond wrote that he inaugurated, on May 22, in Sala Juiz de Fora, the portrait of the daughter of the city's founder, Dona Bertha Halfeld Paleta, also painted by Djanira Diniz. Thus, it is possible to think that the portrait of Father Wilson was included in the collection near that date.

The fact that Father Wilson is of African descent hardly enters the construction of his memory. The journalist Mari Angela Heredia da Costa, in her book about her "uncle priest", makes only a small mention: "Sometimes she would also do the program with the military captain-chaplain's uniform, which caused a certain frisson in the female audience: 'there comes the chocolate in uniform.' They said, in reference to its very dark color."(COSTA, 2003, p.33)
12- Participated in the First Women's Salon of Plastic Arts of Juiz de Fora, in 1969. https: // www.guiadasartes.com.br/djanira-dinis/obras-principal.] 


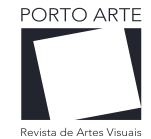

VERSÃO

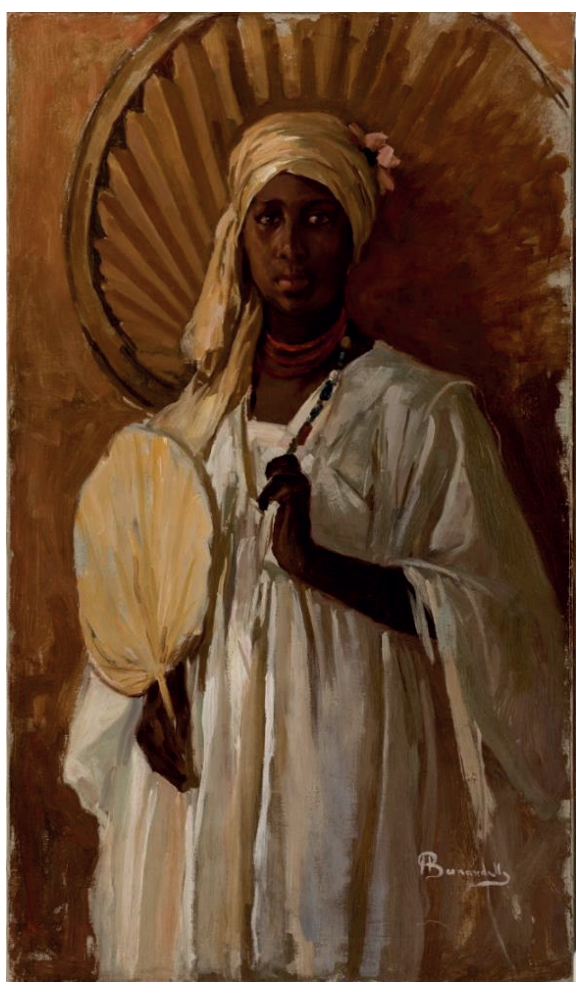

Figure 2. Henrique Bernardelli, Etíope, s.d., Oil on canvas, 126 $\times 73 \mathrm{~cm}$., MMP (Reproduction Mariano Procopio Museum)

13- Henrique Bernardelli, Etíope, s/d. Oil on canvas, $125,8 \times 73,3$ $\mathrm{cm}$., MMP.

14- "Henrique Bernardelli's exposition". A Notícia. Rio de Janeiro, 4-5 de junho de 1916
If the representations of the former slave at the foot of Princess Isabel were a logical choice of the monarchist collector, and the portrayal of Father Wilson, the director's tribute, Geralda Armond, to an ally in the fight against communism, the other works depicting African descent imposed on the institution, making the collection of the Mariano Procopio Museum richer and more exciting.

\section{Donated Or Legacy Works}

Three works of African descent are found in the museum at the will of the artists who donated them at different times: Henrique Bernardelli, Armando Vianna and Alcides Cruz.

Henrique Bernardelli's canvas ${ }^{13}$ (1857-1936) was transferred to Alfredo Ferreira Lage's collection in 1937, when he integrated the part of the artist's collection destined to the Mariano Procópio Museum (LEE, 1991, p.20-21). She is cited in the 1944 collection with the title Ethiopian.

In the painting, a black woman occupies the entire space of the canvas, represented standing, almost full length. Rustic white robe, reflecting the ocher tones of the abstract background. He holds with his right hand a straw vent, and with his left one of the necklaces around his neck. The head is wrapped in turban. Surrounding it, like a large halo, is a streaked structure, reminiscent of a palm tree, perhaps a stylized date palm. The woman looks straight at us, her calm countenance and fine features.

The earthy tones harmonize with the color of the skin, bringing it closer to nature. The tunic, turban, fan, necklaces and possible date palm leaf characterize her as a distant being. The necklaces in particular recall those worn by Ethiopian women.

The screen is not dated. From the size $(125.8 \times 73.3 \mathrm{~cm}$.), This is not a mere study, it was possibly intended for some exhibition. However, it does not appear among the works sent by Bernardelli to the General Exhibitions of Fine Arts (EGBA), in which the painter participated with assiduity.

The permanence of the work in the artist's studio, until his death, allows us to think that the canvas was not successful with buyers, or be very dear to the painter, who did not want to sell it.

Although Henrique Bernardelli's vast production over the 79 years of its existence has not yet been cataloged, there are few known works in which the artist represented African descendants. In the artist's solo show in 1916, composed of 136 works of all genres, the newspaper A Notícia referred to the Baiana painting, not located: "Bahiana" is very natural, reinforced mulatto, black eyes, sweet expression and basket of delicacies on the side, especially emphasizing the good-looking air that comes to her in physionomy "14 
You can see that Baiana and Ethiopian operate on close records. We can think of both as picturesque visions of a black woman, especially the baiana bonachona. Baianas, greengrocers and street vendors have vast iconography, ranging from melancholy figures such as Debret's Negra tatuada vendendo caju ${ }^{15}$, and Antonio Ferrigno's ${ }^{16}$ Preta quitandeira, to the sensual figures of our modernism.

However, classifying Ethiopian only as picturesque drains the power of the image. Bernardelli builds a delicate exotic figure, as the orientalist painting, in vogue in the nineteenth century, had done, but without great sensual appeal (PELTRE, 2010), emphasizing its dignity.

While Henrique Bernardelli resorted to the well-known strategy of representing an exotic and distant being, another artist present in the museum's collection, Armando Vianna, presents us more realistically as a maid polishing silver and crystal. ${ }^{17}$

Armando Vianna (1897-1992), unlike Bernardelli, is today an almost unknown painter. He pursued a conventional career for a simple young man from Rio de Janeiro: at thirteen he began working at his father's painting workshop, painting plates, carts and buggies; attended the High School of Arts and Crafts, the free course at the National School of Fine Arts, where he was a student of Rodolpho Amoêdo and Rodolpho Chambelland; In 1921 he began his participation in the General Exhibitions of Fine Arts, winning the travel award, in 1926, with the Spring in Bloom canvas, exhibited at the National Museum of Fine Arts. He survived his artwork by painting flowers, landscapes, female nudes, historical and religious canvases, dying in 1992 at the age of 95 (CARNEIRO, 1988).

Vianna painted Limpando Metais, probably aiming to compete for the prize at the 1923 General Exhibition of Fine Arts, winning the Silver Medal. At first we did not seem to have Armando, though grateful slave grandson, produced many paintings with black characters ${ }^{18}$, but at the 1941 National Salon of Fine Arts the artist sent Bitter Life, where he presents, in large format, two blacks picking bananas, winning the Brazil Travel Award. ${ }^{19}$

The trajectory of Limpando Metais between the 1923 Exhibition and its entry into the Mariano Procópio Museum is unknown. The painting was offered as a donation to the museum by the author in 1967 at the age of $70 .{ }^{20}$

The artist inserts the black woman as a domestic worker in a family home. It occupies almost the vertical half of the screen; her figure, however, appears out of place, sandwiched between a table full of objects and the cabinet in the background.

The maid cleans the metals without the slightest interest. Sad and bored, does not challenge us. Armando Vianna not only represents a black woman in the role of a maid, but seeks to recover her humanity as she turns her attention away from work. She is not just a social type, like black women represented by nineteenth-century travelers, for example.

It is possible to bring the maidservant's demeanor closer to the insight of the waitress at Un bar aux Folies-Bergère, painting by Edouard Manet ${ }^{21}, 1882$.
15- Jean Baptiste Debret, Negra tatuada vendendo caju, 1827. Paperless watercolor, 15,5 × 21 $\mathrm{cm}$. Chácara do Céu Museum, Rio de Janeiro.

16- Antonio Ferrigno, Mulata quitandeira, (entre 1893 e 1903) Oil on canvas, $179 \times 125 \mathrm{~cm}$. Pinacoteca, São Paulo.

17- Armando Vianna. Limpando metais, 1923. Oil on canvas, $99 x$ $81 \mathrm{~cm}$., MMP.

18- Assertive based only on reading the book by José Maria Carneiro.

19- Work not yet located, but reproduced in: Correio da Manhã. 08/31/1941; O imparcial, September 3, 1941;A noite ilustrada, 9/23/1941; and O malho, oct. 1941, p. 47. Armando Vianna exposed Vida Amarga in the general section. Although presenting a black worker, the title empties the positive potential that could be attributed to the work, especially after Portinari's valorization of the black worker, such as the Mestiço and Lavrador de café, on 1934.

20- In a letter dated 25/04/1967, from the Director of the Mariano Procopio Museum to Armando Vianna, Geralda Armond accepts the artist's offer Historical Archive of the Mariano Procópio Museum.

21- Edouard Manet. Un bar aux Folies-Bergère. 1882. Óleo s/ tela, $96 \times 130 \mathrm{~cm}$., Courtauld Institute Galleries, Londres 


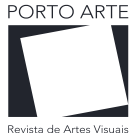

VERSÃO

22- Modest Broccoli, Engenho de mandioca, 1892. Oil on canvas, $58.6 \times 75.8 \mathrm{~cm}$. MNBA. Modest Broccoli, Redenção de Cã, 1895 Oil on canvas, $199 \times 166 \mathrm{~cm}$. MNBA. Lucílio de Albuquerque, Mâe-preta, 1912. Oil on canvas, $150 \times 112 \mathrm{~cm}$. Bahia Museum of Art.

23- Tarsila do Amaral, A negra, 1923. Oil on canvas, $100 \times 80$ $\mathrm{cm}$., MAC USP.

24- From 2009 forward, the painting of Armando Vianna became known through CHRISTO, 2009 and BINDMAN, 2014, vol. $\checkmark$, part 1

25- About this, see HILL, 2007 26- Alcides Cruz, s.t., s.d (c. 1975). Oil on canvas, $73 \times 60 \mathrm{~cm}$. MMP.

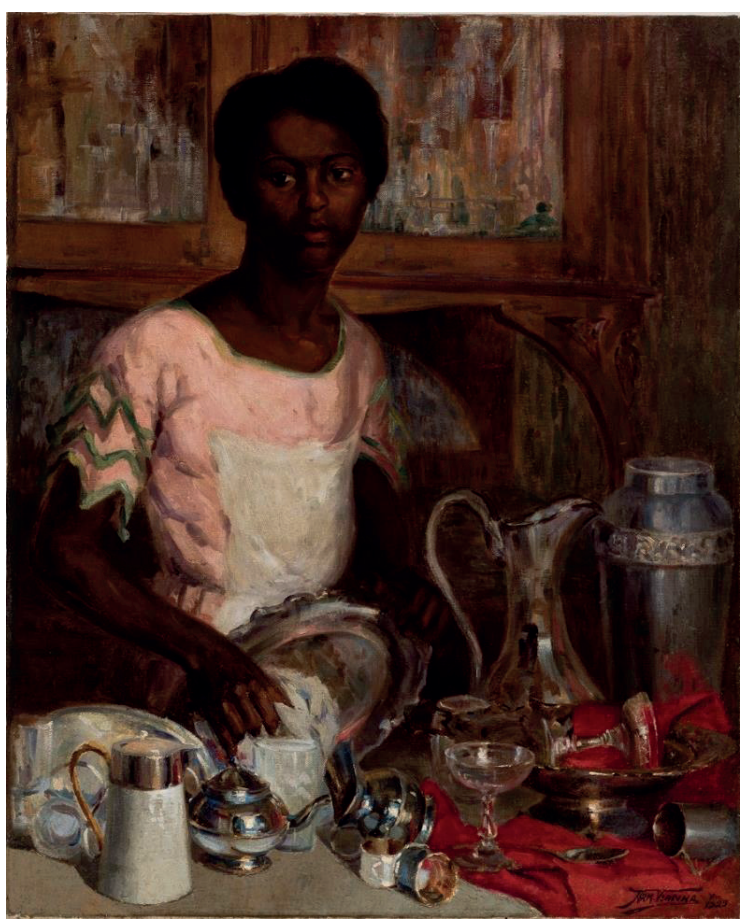

Figure 3. Armando Vianna. Limpando metais, 1923. Oil on canvas, $99 \times 81 \mathrm{~cm}$. MMP (Reproduction Mariano Procópio Museum)
Much has been written about Manet's painting, both about its ambiguities and about the place occupied by the waitress (CLARK, 2004). We focus only on the humanization of the clerk, in her discomfort, alienation and sadness, in contrast to the festive atmosphere of a Parisian concert café.

Confined between the table and the cupboard, Vianna's maid also alienates herself from her surroundings. Approaching Manet's representation, the Brazilian painter gives a universal dimension to the solitude of the black maid.

Limpando Metais fits into an image production that, although tiny, has been established since the abolition. Even without a rigorous survey, the best known paintings allow us to understand the concern about the place of black women in Brazilian society. The options identified in the works are pessimistic: disappearing by miscegenation, remaining reclusive in the periphery and hills or imprisoning themselves in the kitchen, always working ${ }^{22}$. The alienation of Armando Vianna's black woman is, in a way, the awareness of this process.

Precisely in 1923, two black women come into play: one by Armando Vianna, one by Tarsila do Amaral ${ }^{23}$. The story is already known: Armando exhibits his at the 31st General Exhibition of Fine Arts, in which he receives the Silver Medal; After a few decades it is incorporated into the collection of the Mariano Procopio Museum, where it will remain forgotten ${ }^{24}$. As for the black produced in Paris by Tarsila, enthusiastically displayed by Fernand Léger to his students, reproduced on the cover of poems written by Blaise Cendrars, it quickly became a symbol of absolute rupture (AMARAL, 1975, p. 97-98).

Tarsila's A Negra is an archetype. After her, Brazilian modernism produced a significant number of black and mestizo representations ${ }^{25}$. It is not our aim to challenge its undeniable historical importance, only to inquire about the production obliterated by the modernist militancy that celebrates it; production that is, in part, present in museums such as Mariano Procópio.

The two canvases raised here, Etíope, by Henrique Bernardelli, and Limpando Metais, by Armando Vianna, reveal two different ways of approaching the same theme, the representation of the black woman. One as an exotic and distant being, another as a maid. However, they are equal in respect for the characters, in the strength of humanity they express.

In 1975, another work was added to the representations of Henrique Bernardelli and Armando Vianna, donated by its author, Alcides Cruz ${ }^{26}$. Next to Armando Viana, Alcides Cruz was 62 years old, when his canvas became part of the museum's collection. 
Alcides Cruz (1913-1987) began his studies in 1931 at the age of 18 at the Rio de Janeiro High School of Arts and Crafts. He attended the National School of Fine Arts, where he was a student of Henrique Cavalleiro, Carlos Oswald and Alfredo Galvão. At the same time, he graduated as a dentist in 1937 from the National School of Dentistry of the University of Brazil; In this profession, he worked for the Army, where he retired in 1982. ${ }^{27}$

The artistic career developed more slowly. Alcides Cruz participated in the National Salon of Fine Arts (SNBA), where he obtained, in 1954, Silver Medal; in 1966, Gold Medal; and in 1970, the Travel Abroad Award. In the 1970s, Alcides exhibited at Rachid Gallery, by whom he was released to the market. ${ }^{28}$

Having received the Travel Award, Alcides embarked for Europe in July $1972^{29}$ for a 2-year stay. During this period, he opened, on February 8, 1973, after attending the S. Fernando Superior School of Fine Arts, in Madrid, an individual exhibition at Casa do Brasil. Lived in Paris at the Quartier Latin, Boulevard Saint Michel. Also, in 1973, he headed to London, where he performed solo, under the auspices of the Brazilian Embassy. In Italy, he entered, by competition, the Accademia di Belle Arti di Roma.

It is possible that the work donated to the museum in 1975 was produced after this long journey of the artist. In an interview with the Arriba newspaper of February 11, 1973, when he was an individual at the Casa do Brasil in Madrid, the painter stated: "My painting is especially expressionist. I try to shape my mischief as I see it. It inspires me for any reason: monuments, elements of the human figure, costumes, typical costumes. Everything interests me." ${ }^{30}$

The donated painting is undated and has no title. It features a black woman, occupying the entire screen, sitting in front, in Bahian garment, with a shoulder cloth on her left shoulder, bracelets, necklaces, earring and turban on her head, looking at a pan. As the artist himself stated, he was inspired by his human figure, typical customs and costumes, without further questioning. The black woman of Alcides Cruz could be placed in the long tradition of the greengrocers, who later became Bahian. The isolation of the figure, its concentration in relation to the pan, allows us to raise the hypothesis of the artist representing a terreiro scene, the preparation of some orisha's food.

In the 1970s, when the work was donated to the museum, there was widespread interest in Afro-Brazilian religions. Reginaldo Prandi, sociologist, has historized this process. According to him, the history of Afro-Brazilian religions can be divided into three moments:

"primeiro, da sincretização com o catolicismo, durante a formação das modalidades tradicionais conhecidas como candomblé, xangô, tambor de mina e batuque; segundo, do branqueamento, na formação da umbanda nos anos 1920 e 30; terceiro, da africanização, na transformação do candomblé em religião universal, isto é, aberta a todos, sem barreiras de cor ou origem racial, africanização que implica negação do sincretismo, a partir dos anos 1960." (PRANDI, 1998., p. 93-111)
27- http: //alcidesgomescruz. blogspot.com/p/bibliografia.html

28- O Jornal, Rio de Janeiro, 06/09/1972, p. 6.

29- Jornal do Brasil, Rio de Janeiro, 22/06/1972

30- LOUZADA, Maria. In: CABICIERE, 1987 


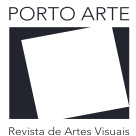

VERSÃO

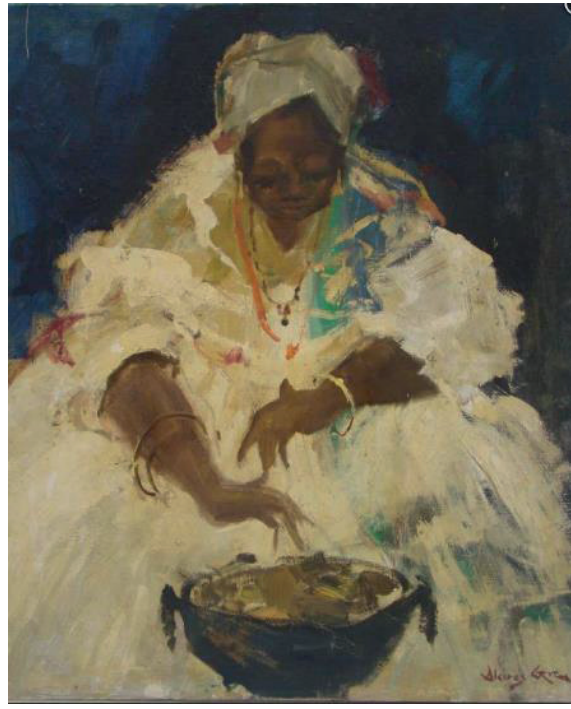

Figura 4. Alcides Cruz, s.t., s.d (c 1975). Oil on canvas $73 \times 60 \mathrm{~cm}$. MMP (Reproduction: Mariano Procópio Museum)
It is noticeable that black religions were always present, although attenuated in the first moments, by syncretism with the Catholic religion, or by the subsequent approach with the spiritualism of Alan Kardec, promoted by the Umbanda. Despite the process of opening Umbanda to white society, it was still viewed with prejudice as a black religion, remaining among the poorer middle class, controlled by the police and public health. Called "low spiritualism", the Umbanda did not attract intellectuals, artists and journalists of expression. The opposite happened with candomblé. Since its inception, the latter has been surrounded by influential people in society: "intellectual professionals who nurtured by the black religion sympathy and admiration and who maintained with the terreiros of candomblé and their leaders affective and solidarity bonds" (Prandi, 1998). They held a hierarchical position, a kind of protective father, the ogá, a bridge between the terreiro and the white world.

The 1960 s and early 1990 s are also characterized by counterculture, the pursuit of the exotic, the different, the original; something that can be found in Bahia. Resistance to dictatorship by leftist movements, especially youth, led to the appreciation of the poor, the black, the exploited and marginalized, including Rio's favelas and hills, with many reflections on artistic production.

Also during this period, candomblé, which remained in Bahia stuck to its origins, reaches mainly the Southeast region, thanks to northeastern migrations. The reunion with the rich cultural heritage of black religions has provided popular culture with much of its repertoire. Converted into profane art for mass consumption, black religions, especially candomblé, in return received recognition and prestige.

The Alcides Cruz painting, dated by the museum of c. 1975, would share this context. Let us remember that in 1969 Jorge Amado published Tenda dos milagres; In 1974, Nelson Pereira dos Santos released the movie Amuleto do Ogum; and in 1975 Clara Nunes recorded the song A Deusa dos Orixás on the album Claridade. With regard to the fine arts, it is sufficient to remember the importance of orishas in the works of painter Carybé and photographer and ethnologist Pierre Verger.

On the part of Henrique Bernardelli, Armando Vianna and Alcides Cruz, it is clear that, in old age, they direct works to public spaces, in the desire to build a memory denied by modernist historiography. They are works dating from different periods, but inserted in a next figurative tradition, which, in this respect, do not differ much from the collection of the Mariano Procópio Museum. They were incorporated in a completely random way, not translating any institutional effort, but rather the commitment of the artists who donated them. 


\section{Acquisition Award In The Hall Of The Fine Art Society Antônio Parreiras, 1950-1970}

From the 1930s to the 1950s, artists began in Juiz de Fora an associative process aimed at having a place to paint, share a living model, form a library, teach some classes, exchange experiences and assert themselves as artists. A process common to many places in the country, which provided multiple experiences of a modernist understated aesthetic. Thus was created, in 1934, the Nucleo Antonio Parreiras, transformed in 1941, Society of Fine Arts Antonio Parreiras (SBAAP).

The SBAAP was characterized by the humble social position of most of its members, by the concern with the formation and professional performance, with the democratization of the teaching. His works had a simple theme, attached to daily life, valuing the urban periphery. Some of its members were of African descent, such as Marcos de Paula and Lage das Neves, represented in 1952 by Angelo Bigi in the group portrait Artists of SBAAP, belonging to the museum's collection. ${ }^{31}$

Although, since the 1930 s, Parreiras faced problems common to this type of organization - such as the lack of its own headquarters, the inconsistency of its members and/or students, the lack of interest of the government, the simultaneous exercise of other professions, etc.-, the early 1950s were seen as promising. In 1950, the SBAAP organized the "Art Exhibition in Commemoration of the Juiz de Fora Centenary", in which it distributed 5 acquisition awards, subsidized by the municipal government, based on Law No. 99 of December 2, 1948, which established the Municipal Official Salon. The periodicity of the hall and the purchase awards boosted the local artistic environment. The acquired works were sent to the Mariano Procópio Museum.

It was from the acquisition prize that most of the works representing African descendants and their culture (as perceived at the time) entered the museum's collection. Although less valued by the artistic system, its sociological importance is significant.

\subsection{Works Of Members Of The Fine Art Society Antônio Parreiras}

Initially, it is noteworthy, in the set of works sent to the museum due to the acquisition awards, the works produced by members of SBBAP: Luiz Soruleiro, Jaimi Soares Costa, Wandyr Elídio Ramos and Carlos Bracher. ${ }^{32}$

Luiz Soruleiro (1914-1988), a native of Juiz de Fora, where he always lived, worked in his father's marble factory, dedicating himself concurrently to drawing and sculpture. Became a prosperous businessman. The work present in the museum is the bust of a black woman in plaster, signed and dated $1950^{33}$. Performed without further ambition, the study accentuates the character's ethnic characteristics. In the museum there are references to having the work received a prize from the 1950 Salon, however, it is not in the exhibition catalog ${ }^{34}$. Also in the museum the work is sometimes referred to as "Noca", sometimes as "Mestiça".
31- See CHRISTO, 2019

32- See biographical data in: AMARAL 2004.

33- Soranço, Noca (Mestiça), 1950. Plaster, $32 \times 21 \times 23 \mathrm{~cm}$

34- The works: Expedicionário; Cabeça de criança; Índia; Cabeça de Cristo; Maquete. 


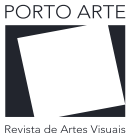

VERSÃO

35- Jaime Soares Costa, Retrato (Cabeça; Cabeça de jovem negro), c. 1953. Óleo s/madeira, $35 \times 49$ $\mathrm{cm}$., MMP.

36- Wandyr Elídio Ramos, Autorretrato, 1970. Oil on canvas, $65 \mathrm{~cm} . \times 57 \mathrm{~cm} ., \mathrm{MMP}$

37- Carlos Bracher, Colega Wandyr, 1960. Oil on canvas, $64 \times 54 \mathrm{~cm}$., MMP. Probably, during this same period, Carlos Bracher did a head study, representing the same painter. http://artetecta.blogspot. com/2010/06/bracher-um-resistente-da-pintura.html
Jaimi Soares Costa (1917-1992), at the beginning of the 1950s, began his studies at SBAAP, participating in the 1953 Salon, a year in which he also exhibited at the National Salon of Fine Arts, in Rio de Janeiro. He is an artist of recognized quality, mainly in terms of drawing. In the museum is the painting "Cabeça de Jovem Negro", also referred to as "Retrato", signed and undated ${ }^{35}$. It is a strong representation, where the young man appears serious and melancholic. The datasheet puts is at c. 1953. In this year's exhibition catalog, there are two paintings by Jaimi Soares, both identified as "Cabeça."

Wandyr Elídio Ramos (1935-1998) was born in Juiz de Fora, the son of a cook father and a working mother. He also began his studies at SBAAP in the 1950s. He has participated in several SBAAP salons, being awarded in some. In 1970, he exhibited three works: Auto retrato, Preto and Paisagem, having received the Acquisition Award for Auto retrato ${ }^{36}$. Wandyr's self-portrait is vibrantly structured, built with long, pasty brush strokes, reminiscent of Van Gogh's self-portraits. At this point, Waldir Ramos already had symptoms of mental illness, which led to his hospitalization until the end of his life.

Ten years earlier, in 1960, Wandyr was portrayed by his colleague Carlos Bracher (1941) in the studio, full-length, sitting, with brush in hand, melancholy pose, facing the observer ${ }^{37}$. Emphasis is given to the solitude of the artist; the canvas that hypothetically Wandyr would be painting does not appear. Bracher's painting was exhibited and awarded the Acquisition Award. At the age of 19, Carlos Bracher began a promising career; he belonged to a generation that sought to renew SBAAP, and will later transfer to the Celina Art Gallery, an important space for local culture in the 1960s (PEREIRA, 2015).

Interestingly, the four works acquired from members of society itself are portraits, mostly possible studies.

\subsection{Articles Of Artists Members Of The Company Of Fine Art António} Parreiras.

Throughout the twentieth century, Brazil saw the gradual process of making the modernist aesthetics hegemonic in the country. In 1933, the General Exhibitions of Fine Arts became the National Salon of Fine Arts. In 1940, within the National Salon of Fine Arts, the Modern Division was created, maintaining the General Section, with separate awards. In 1952, the Modern Division became the National Salon of Modern Art, leaving the National Salon of Fine Arts to defenders of a more traditional art, being derogatively referred to as the "academic hall". Thus well-defined fields were established. Around this emptied National Salon of Fine Arts and various regional halls, gravitated artists, sometimes without much training, who practiced a correct design, incorporating looser brushstrokes and lighter colors. These were the artists attracted by the acquisition prize of the Salon of the Society of Fine Arts Antonio Parreiras. 
Let us begin with a dry pastel drawing on paper, $61 \mathrm{~cm} \times 49 \mathrm{~cm}$., Dated June 10, 1954, entitled Mau Passo, signed by Salvador Rodrigues Jr. The artist was born in Cadiz (Spain) in 1907, came to Brazil in 1911, settling in São Paulo, where he died in 1995. It is known that he graduated in painting at the "Male Professional School of the State of São Paulo", frequently exhibiting at the Paulista Salon of Fine Arts and the Salon de Piracicaba ${ }^{38}$. In 1954, at the age of 47, Rodrigues Jr. sent the design to the SBAAP Salon, receiving the second acquisition award.

The work depicts a young man, from the waist up, with his left elbow resting on a table, holding his head thoughtfully. A glass of brandy and a cigarette are on the table, justifying the title: Mau Passo. It is an interesting work, demanding more attention.

Drunkenness has long been represented in the history of

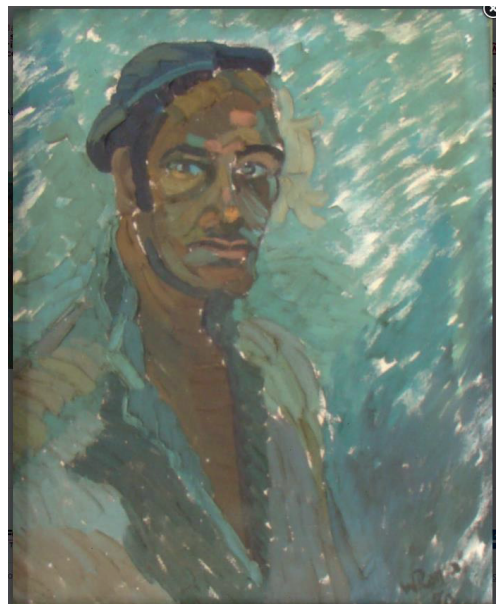
art. However, we are interested in realistic production focused on human drama, such as the works of Alber Anker, Der Trinker, 1866, and Antonio Esteban Frías, El Borracho, 1901. In these cases, the characters are lonely, with the glass in their hands, externalizing in the bodies the consequences of addiction. However, Salvador Rodrigues Jr's drawing is more complex. By representing a black man, it goes beyond universal human pain and strengthens racial prejudice. The idea of the black as a degenerate, vain and alcoholic was present in racial theories, especially in eugenism, as well as in journalistic chronicle.

In the history of Brazilian art there is another representation of a black man accompanied by a glass of cachaça and a cigarette. It is a painting by Arthur Timótheo da Costa, dating from 1921, from a private collection, exhibited in a commemorative exhibition on the 130th anniversary of the abolition, at the Afrobrasil Museum. Surprisingly, like a mirror to Rodrigues Jr's young man, Arthur presents his character with his right elbow propped on the table, holding his head, half-full glass and cigarette in his mouth; is an adult in whom the effects of alcohol become evident. Why would Arthur Timótheo da Costa, a black artist, paint, shortly before his death, a reaffirming work of a prejudice so ingrained in Brazilian society? Was there intentional relationship between Rodrigues Jr's work, 33 years later, and Arthur's canvas? How artists deal with stereotypes is the big question posed by Mau passo.

Interesting to note is the character of Salvador Rodrigues Jr. a young man, with the glass and cigarette still untouched. Given this, he wonders if the boy might have a better destiny. If the title condemns it, the image does not. The screen is dated 1954, three years after the Afonso Arinos Act was passed, criminalizing racism. The racial democracy proposed by Gilberto Freire in the post World War II era was still seen as a possibility, it is a period in which the black man "fights for his right to the Law", in the words of the actor and black activist Abdias Nascimento. That is, the young man is not a condemned man, as racist theories touted, he may become the lord of his destiny (ALBERTO, 2014, 377-401), despite the regrets.

Figura 5. Wandyr Elídio Ramos, Autorretrato, 1970. Oil on canvas, $65 \mathrm{~cm}$. $\times 57 \mathrm{~cm}$., MMP (Reprodução Museu Mariano Procópio)

38- SALVADOR Rodrigues. In: ENCICLOPÉDIA Itaú Cultural de Arte e Cultura Brasileiras. São Paulo: Itaú Cultural, 2019. Disponível em: <http://enciclopedia. itaucultural.org.br/pessoa8816/ salvador-rodrigues> 


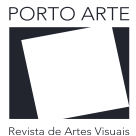

VERSÃO

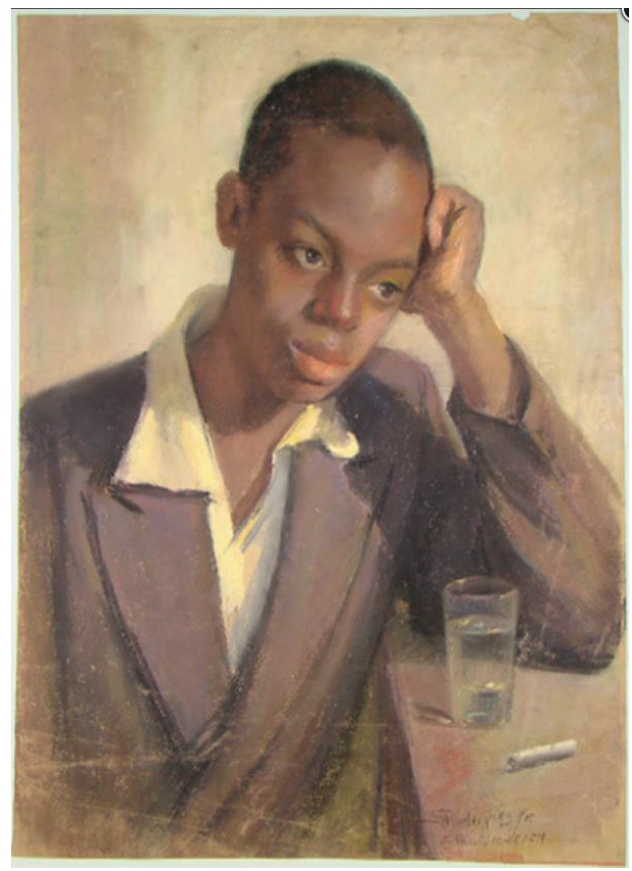

The other works acquired at the SBAAP Salon from exhibitors outside Parreiras are concentrated in the 1970 s.

The small oil on wood by Arlindo Mesquita (19241987 ) is also the head of a black man, very representative of his personal style ${ }^{39}$, where the figure appears a little liquefied. The character appears in a hat, looking up, with no apparent religious connotation. The painting was awarded at the 1977 SBAAP Salon. At that time, Arlindo Mesquita was already an experienced artist, 53 years old.

His trajectory is common to the artists who exhibited at the SBAAP Salon. Born in Arco Verde, Pernambuco, in 1924, his father was a fisherman; at 13 he went to Recife, where he started painting and sculpture as a self-taught person. At 15 he joined the Pernambuco School of Sailor Apprentices, continuing in the navy until 1944, when he joined the reserve as a disability sergeant, a victim of the torpedoing of the Vidal de Oliveira transport vessel by the German submarine U-861 during World War II. Worldwide. He settled in Rio de Janeiro, working with advertising design, teaching and selling paintings on the street ${ }^{40}$.

Arlindo Mesquita lived in the Rio de Janeiro suburb

Figura 6. Salvador Rodrigues Jr., Mau Passo, 10/06/1954. Dry pastel on paper, $61 \mathrm{~cm} \times 49 \mathrm{~cm}$. MMP (Reproduction: Mariano Procópio Museum) 39-Arlindo Mesquita, s / t., 1977. Oil without Eucatex, $27 \times 18 \mathrm{~cm}$., MMP

40- LEITE, 1988. PONTUAL, 1969. The Journal, Rio de Janeiro, $10 / 26 / 1968$

41- Caetano Veloso "I am Vinícius de Moraes". In: MORAES, 2008. 42- Journal of Brazil, Rio de Janeiro, 12/14/1967

43- "Brazilian painter Arlindo Mesquita exhibits at the Independent Gallery in Los Angeles. The show is organized by mr. Phillip Treitel, owner of the gallery, who has already exhibited several Brazilians in his home. Correio da Manhã, 02/26/1966, $2^{\circ}$ Caderno, p. 3 44- O Fluminense, Rio de Janeiro, 03/11/1969

45- Jornal do Brasil, Rio de Janeiro, 08/12/1967

46- Jornal do Brasil, Rio de Janeiro, 14/12/1967

47- O Jornal, Rio de Janeiro, 26/10/1968 of Marechal Hermes, where he taught. Caetano Veloso, for example, in 1956, at the age of 13, lived in Guadalupe, near Marechal Hermes, and took painting classes $^{41}$ with him.

Mesquita began exhibiting outdoors on St. Joseph Street, along with other anonymous painters who formed the Independent Artists Movement ${ }^{42}$, when he was invited in 1965 to present his work in the USA ${ }^{43}$. In the 1960s, he became a painting professor at Casa do Marinheiro, in Rio de Janeiro, during which his name begins to appear in some exhibitions of the most conservative circuit, to which we have referred, such as the National Salon of Fine Arts. Arts (Honorable Mention, 1963; Bronze Medal, 1964; Silver Medal, 1965), Fluminense Salon of Fine Arts (Cash Prize, $1969^{44}$ ) and the Salon of the Brazilian Society of Fine Arts. In 1967, he was awarded the Paris Travel Prize at the 2nd Pancetti Salon, organized by the 1st Naval District at the National Museum of Fine Arts, in celebration of Navy Week ${ }^{45}$. The exhibition brought together works by active, retired and retired military personnel, as well as their families. ${ }^{46}$

In his studio, Arlindo Mesquita painted popular themes: slums, cangaceiros, processions and many faces, such as the one belonging to the Mariano Procópio Museum. In an interview with 0 Jornal, in 1968, gives details of his life, manifests himself against the vanguards, and is called by reporter Glauco Carneiro "cabloco"47. About the faces, the reporter wrote: "The faces that Mesquita makes 
appear in his paintings are faces of anguish, restlessness, of fear, but not the aggressive anguish, because it gives her pity, incites the action to alleviate it. ) "

In the 1970s, he is still exhibited at the National Salon of Fine Arts (1972 Gold Medal, Brazil Travel Award 1973, Overseas Travel Award 1974) ${ }^{48}$. We do not know exactly when he traveled to Europe, but in 1976, he returned to Brazil for health problems. He exhibited in Goiânia, at the end of that same year, and there suffered a crisis of liver cirrhosis, only recovering in November $1979.4^{49}$

Following the chronology of his life, built from news in the periodicals, it is clear that the work sent to the SBAAP Salon, dated 1977, was theoretically produced in this context back to Brazil and treatment of a difficult disease. This period is a turning point in Arlindo Mesquita's career, according to critic Walmir Ayala, for his award at the 1st National Salon of Fine Arts, promoted by FUNARTE, in 1978, arising from the merger of the extinct National Salon of Modern Art and National Salon of Fine Arts. ${ }^{50}$

We cannot evaluate Ayala's statement because of the lack of more systematic knowledge of the artist's work; However, one can notice the existence of two interesting narratives.

In most interviews, Arlindo Mesquita invests in the idea of continuity: he reaffirms his fidelity to the poor northeastern origin, self-taughtness, freedom from artistic styles, as well as aversion to the avant-garde. The theme of his works remained constant, between the poverty of the Northeast and the sea, but, according to Arlindo Mesquita himself, his painting "was never of the political-doctrinal type". ${ }^{51}$

On the other hand, Walmir Ayala, writing in 1986, claimed to have participation in the former salons and academic coexistence kept the artist in the "disciplinary corset of conventional orientation". However, the painter would have read and acquired in two years of hospitalization:

\footnotetext{
"Theoretical support for future research. He was saved not only from illness, but from the danger of remaining academic, and it was at the National Salon of Fine Arts, the revamping stage of the Old National Salon, which he earned an acquisition prize, in addition to the highly evaluative significance. of passing through careful selection. ${ }^{52 "}$
}

That is, the critic tries to justify how an artist, with a career shaped by the "academic corset", can be awarded at the new National Salon of Fine Arts. As for the painting of Juiz de Fora, because it was produced in 1977, midway, would it reflect which phase? Impossible to answer for now.

If Arlindo Mesquita is a little known artist, the other artists whose works represent African descent and were acquired at the SBAAP Hall are even less so.
48- Correio Brasiliense, Brasília, $18 / 03 / 1984$

49- Jornal do Brasil, Rio de Janeiro, 04/02/1980

50- Democratic struggle, Rio de Janeiro, 11/17/1978. Mesquita wins Travel Award.

51- Tribuna da Imprensa, Rio de Janeiro, 19/03/1980

52- Jornal do Commercio, Rio de Janeiro, 04/08/1986 


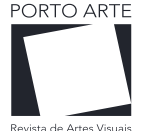

VERSÃO

53- Antonieta Santos Feio, Vendedora de cheiro, 1947. Oil on canvas, $105 \times 74 \mathrm{~cm}$, Museu de Arte de Belém

54- In 1975, exposed on City Park, in Gávea. O Jornal, Rio de Janeiro, 09/09/1975.

55- Tribuna da Imprensa, Rio de Janeiro, 18/11/1960; 0 Fluminense, Rio de Janeiro, 29 e 31/08/1962.

56- O Globo, Rio de Janeiro, 23/11/1965

57- O Jornal, Rio de Janeiro, 28/09/1968

58- Última Hora, Rio de Janeiro 24/11/1962

59- O Fluminense, Rio de Janeiro, 12/06/1962

60- O Fluminense, Rio de Janeiro, 02/06/1966
At the 1970 SBAAP show, Eleonora de Figueiredo presented two paintings: A moça com lenço and A mestiça, the latter being acquired by City Hall.

A mestiça represents the bust of a young, mulatto or cabocla, hard to know, with a pink flower in her hair. It is presented from $3 / 4$, directed to the left of the viewer, eyes down, practically closed, against a light neutral background. Her lap and arms are bare, the dress appears only as a bust-length band, suggesting no bulk. There is more melancholy than the usual sensuality with which women of African descent are represented. The flower in the hair is an element used in several Brazilian paintings, ranging from sensuality to exoticism, such as some paintings by Di Cavalcanti, and a more regional characterization, as in the work of Pará Antonieta Santos Feio, Vendedora de cheiro, $1947 . .^{53}$

There is little information about Eleonora de Figueiredo. The catalog of the SBAAP Salon shows that she lived in Rio de Janeiro, in Tijuca. Periodicals and the dates of some auction works suggest being active between 1948 and $1975,{ }^{54}$ so she was no longer novice when she sent her works to the Juiz de Fora salon. She has been linked to the Brazilian Society of Fine Arts (SBBA) since the 1960s, participating in its administrative structure, as a member of the fiscal council ${ }^{55}$, or exhibiting. In 1965, for example, she was second placed at the II Women's Salon of Fine Arts, promoted by SBBA, receiving Silver Medal ${ }^{56}$. In 1969, he attended the SNBA LXXIII Salon, alongside Alcides Cruz and Arlindo Mesquita. ${ }^{57}$

Another practically unknown artist is Paulo Ribeiro de Carvalho, present at the 1973 SBAAP Salon, exhibiting an oil work, O frade, and two drawings, $\mathrm{Na}$ batida do samba and Capoeiras, the latter awarded and acquired by the City Hall.

Paulo de Carvalho lived in Niterói, attending the Fluminense School of Fine Arts. This school was maintained by the Fluminense Association of Fine Arts (AFBA), founded between 1938 and 1940, with a similar history to that of SBAAP. The Fluminense Association has also promoted a salon since 1941. Apparently Paulo de Carvalho begins exhibiting in 1962 at the Fluminense Salon ${ }^{58}$ and also at the SBAAP Salon, where he received Honorable Mention. Made reported by the newspaper O Fluminense, with the title "Shined the Fluminense School of Fine Arts in Juiz de Fora": "The Fluminense School of Fine Arts was duly represented at the XII Official Salon of Juiz de Fora, by future artists Geraldo Valentim de Castro Azevedo and Paulo Ribeiro de Carvalho, winning both honorable mentions"59. The term "futures" indicates that Paulo de Carvalho is still a student, unlike Arlindo Mesquita and Eleonora de Figueiredo. Subsequently, we found records of his participation only at the 1st Fluminense Artist Biennial, organized by the Fluminense Association of Fine Arts and the Fluminense Artists Group, in $1966^{60}$ and at the 36th Paulista Salon of Fine Arts, 1971, attended by Armando Vianna and Salvador Rodrigues Jr. In the SBAAP Salon Paulo Carvalho would have exhibited, besides 1962, in the halls of 1970 (Painting: D. Quixote, O lutador) 1973 (works already mentioned), 1975 (painting: Sambistas - Salgueiro, Sambistas - Império Serrano; desenho: Evoluções A, Evoluções B), and 1977 (drawing: Pescador, Lavadeira e Maternidade). 
Paulo Ribeiro de Carvalho's drawing sent to the Museu Mariano Procópio presents in the background, in light gray tones, the flat silhouette of three baianas, with trays on the head, and in the foreground, almost transparent, two figures of capoeiristas in full play, highlighting the movement of bodies with the outline in ink. Bringing together Bahians and capoeiristas, the drawing operates with elements strongly rooted in Bahian culture, at this time universalized and widespread as representative of the Brazilian being. We did not have the opportunity to find any other works by Paulo Ribeiro de Carvalho, evidence of a small production and very restricted circulation, or prematurely interrupted.

The next works analyzed were painted by Valdir da Conceição Silva. Afrodescendant of simple life, the artist was born in Belo Horizonte. He began painting, it seems, at 18 , in 1972, already exhibiting. In 1975 , he participated in the SBAAP Salon in various categories. He presented the paintings Tradição do Brasil I and II, the last one being acquired; the montages A roda da vida, Bumba meu Boi, e Pão nosso de cada dia; as well as the drawings Cabeça de homem, Cabeça de cavalo e Cabeça de galo.; In 1977, he sent to the Salon the paintings Minas, Bahia and Ceará, as well as the drawings Festa I, Festa II and Festa III. In 1979, he exhibited again in Juiz de Fora, with the Baiana painting, also acquired. In the 1990 s, he moved his studio to Contagem, where he apparently continued to paint. He owned a ballroom downtown, decorated with his works, put up for sale. He also offers his works to the public at fairs, suffering, according to him, according to him, a certain prejudice. ${ }^{61}$

They are very colorful works, although the artist is colorblind, presenting a strong decorative tendency. Tradition of Brazil II, from 1975, represents a carnival parade scene, with all black characters. Baianas, in turn, shows two black women, one sitting in front of his board and the other standing with his head in a colonial urban environment. In both paintings the painter's gestures are broad, ignoring details; the faceless characters become impersonal. There is no question about the theme, which has acquired folkloric and decorative features.

Following the Afro-descendant theme, Emigrants was painted by Maria Ely Cezar de Menezes (MELY) and presented at the 1975 Salon, along with the Ouro Preto Ladeira canvas. The picture shows a black family of four walking with belongings on their heads along the side of a paved road in arid terrain. The characters are seen from the back, heading toward the horizon, a little apart from each other. In the foreground, the couple's daughter, in addition to the bundle on her head, carries a small child around her waist who looks back toward us as arguing about her future. The painting explores a common theme at the time - especially if we remember the great drought of 1970 in the Northeast - and a tradition consolidated in Brazilian art, based on literature and Portinari's retreatants. We know nothing about the author, only in the catalog living in Juiz de Fora.

The eleven works acquired during the period by the city hall at the Salon of the Society of Fine Arts Antônio Parreiras were grouped here in two segments: four produced by SBAAP artists and seven by external artists.
61- 0 tempo Contagem, 30/05/2014 - https: //www. otempo.com.br/o-tempo-contagem/artista-encontra-refugio-atraves-de-suas-pinturas- 1.855129 


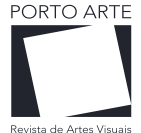

VERSÃO

62- Outside our chronological framework is the painting, Iemanjá tropical, by Marilda Maestrini, a local painting teacher and SBAAP member. Her painting features a feminine, frontal bust surrounded by blue and green tones, without any pretensions. It was acquired at the 1987 exhibition, at which time the city closes the award at the Salon of the Society of Fine Arts Antonio Parreiras.
Other groupings also help to understand this set. Seven artists made portraits: Luiz Soruleiro, Jaimi Soares Costa, Wandyr Elídio Ramos and Carlos Bracher (members of the SBAAP), as well as Salvador Rodrigues Jr., Arlindo Mesquita and Eleonora de Figueiredo. These artists had varied backgrounds, close to self-learning, but they gave the work higher quality. Salvador Rodrigues Jr., Arlindo Mesquita and Eleonora de Figueiredo circulated through the traditional halls, still said academics, having a more consolidated career. The other four works, where one cannot perceive the same quality, present themes related to black cultural life, seen as folklore, decorative, sometimes sold at fairs. ${ }^{62}$

\section{Final Considerations}

The Mariano Procópio Museum is an interesting case to study as the relatively few representations of African descent were incorporated into the collection of the most traditional museums.

Of the seventeen works raised in the collection with this theme, only three works fit the interests of the institution. The former slave at the princess's feet, both in the silver statuette and the monument made by Humberto Cozzo, stands there as a witness to Princess Isabel's benevolence, worshiping the memory of the presumptive heir to the throne. The portrait of Father Wilson Valle da Costa was not in the museum because it recalled some black leadership in defense of a significant part of the population and their culture. The only portrait of an Afro-descendant, with a name and surname, present in the collection at the will of the institution, is of a military chaplain captain, propagator of conservative ideas on a local radio, director Geralda Armond's companion in anti-communist militancy.

The fourteen other works were added to the collection at random, not representing an institutional commitment. Three were donated by painters at different times to build their own memory in a public museum. Henrique Bernardelli's A Etíope made up the set of works that existed in the artist's studio, divided by the painter's estate among several institutions, including the Mariano Procópio Museum, without knowing the criteria for the fate of each piece. It is a delicate work, which dignifies the black woman, however, in distant origin. The 1944 listing indicates that she remained on display in the Maria Amalia Room, perhaps more because she carried the signature of a respected artist and had pictorial quality, and less for the theme. Apparently, brothers Bernardelli, Henrique and Rodolpho, were close to Alfredo Ferreira Lage.

Three decades later, in 1967, Armando Vianna donated his painting depicting a black woman cleaning metals to the museum. Although not as well-known as Henrique Bernardelli, her canvas received the distinction of a Silver Medal at the 1923 General Exhibition of Fine Arts, which qualified her to also be part of the exhibition circuit. 
Alcides Cruz's painting was donated approximately in 1975, in the context of valorization of black culture, although still coated with a certain exoticism. There is no record that this painting has been exhibited.

The eleven works acquired by the City Hall of Juiz de Fora at the SBAAP Hall and sent to the Mariano Procópio Museum are numerically expressive.

Six feature head studies, including a self-portrait; These are works by members of SBAAP itself or by artists who circulated in more traditional salons, such as the National Salon of Fine Arts, the Salon of the Brazilian Society of Fine Arts and various regional halls. They are artists of a certain technical quality, admired by a medium market, receptive to traditional design. In addition to these works, Carlos Bracher's representation of his colleague Wandyr.

The other four works explore black culture (carnival, baianas, capoeira) as well as social problems (withdrawals). However, the themes are treated in a folkloric and decorative way by mostly self-taught artists. These works were acquired in the 1970s, during which the Salon of the Society of Fine Arts Antonio Parreiras had decayed.

Apparently, the works cited, acquired by the city hall at the SBAAP Hall, were never exhibited at the museum. They are perceived as the result of unjustified interference by the municipality in the institution.

A work has not been mentioned yet, because it has a very unique trajectory. It is a feminine nude, frontal, pelvis upwards, with a fabric hiding its sex, signed by Gerhardt Kappel, dated 1945 . We know nothing about it, except that it was part of the collection of industrialist Henrique Surerus, a descendant of a family of Germans who settled in Petrópolis, already cited as a donor of torture instruments. The surname Kappel is also present among immigrants from the imperial city, denoting some affective approach. The painting is called Cabocla, but it is clear that the term was taken as synonymous with mestizo. Interesting to note is the only nude among the works representing African descent, unlike other collections. Why did the museum accept the work of an amateur without great technical resources? It is 1945, the demanding collector had passed away, the new director needed support and was seeking to bring the city closer to the museum, Surerus was an important businessman and member of the Friends Council on the Mariano Procopio Museum

The set of works presented makes it possible to think about the vicissitudes of the memory of people of African descent in our museums. It is relevant to discern what is the result of investments of the institution, reflecting its interests, and what is assumed circumstantially, allowing to apprehend other values.

\section{REFERENCES}

ALBERTO, Paulina, "A mãe preta entre sentimento, ciência e mito: intelectuais negros e as metáforas cambiantes de inclusão racial, 1920-1980". In: GOMES, Flávio e DOMINGUES, Petrônio (orgs.) Políticas da raça. Experiências e legados da abolição e da pós-emancipação no Brasil. Selo Negro Edições, 2014, 377-401. 
AMARAL, Aracy. Tarsila - sua obra e seu tempo. São Paulo: Perspectiva, EDUSP, 1975.

AMARAL, Lucas Marques. A Parreiras e seus artistas. Juiz de Fora: FUNALFA Edições, 2004.

BINDMAN, David, GATES JR., Henry Louis. The image of the Black in western art. The twentieth century: the impact of Africa. London: Harvard University Press, 2014, vol. V, parte 1.

CABICIERE, J. (org.) Dez Caminhos na Pintura, outubro de 1987, Arte Hoje.

CARNEIRO, José Maria. Armando Vianna: sua vida, sua obra. Prefácio Jorge Cabicieri. Rio de Janeiro: Arte Hoje, 1988.

CHRISTO, Maraliz de C. V. "Exercícios de desenho no acervo do Museu Mariano Procópio: ser ou não ser a Princesa Isabel?" In: CAVALCANTI, Ana, MALTA, Marize e PEREIRA, Sônia Gomes (org.). Coleções de arte: formação, exibição e ensino, Rio de Janeiro: Rio Book, FAPERJ, 2014, p. 55-68.

CHRISTO, Maraliz C.V. "Algo além do moderno: a mulher negra na pintura brasileira no início do século XX." 19\&20, Rio de Janeiro, v. IV, n.2, abr. 2009.

CHRISTO, Maraliz C.V. "Retratos de grupos de artistas no Brasil: as obras de Arthur Timótheo da Costa e Angelo Bigi". MODOS. Revista de História da Arte. Campinas, v. 3, n. 2, p. 103-124, mai. 2019.

CLARK, T.J. A pintura da vida moderna. Paris na arte de Manet e de seus seguidores. São Paulo: Companhia das Letras, 2004.

CONDURU, Roberto, Arte afro-brasileira. Belo Horizonte: C/Arte, 2007.

COSTA, Joanice G. Entre Cristo e Barrabás: A Ordem Dominicana na crise do Governo João Goulart. Juiz de Fora, 2004 (Dissertação de mestrado, Ciência da Religião, UFJF).

COSTA, Mari Angela Heredia da. PRB - 3 Meu ouvinte, meu amigo: a história do padre Wilson Valle da Costa. Juiz de Fora: FUNALFA, 2003.

DAIBERT JR, Robert. "'Santa Isabel' e o escravo devoto: a princesa redentora por olhares negros e brancos". Anais do Museu Mariano Procópio. Juiz de Fora, v.1, $n^{\circ} 1,2014$.

HILL, Marços, Quem são os mulatos? Sua imagem na pintura modernista brasileira entre 1916 e 1934. Belo Horizonte, 2008 (Tese EBA-UFMG).

IEE, Francis Melvin. Henrique Bernardelli. São Paulo, 1991 (dissertação de Graduação, FAU/USP)

LEITE, José Roberto Teixeira. Dicionário Crítico da Pintura no Brasil. Artlivre, Rio de Janeiro, 1988.

MORAES, Vinicius de, Poemas esparsos, Companhia das Letras, 2008.

PELTRE, Cristina. Orientalisme. Paris: Éditions Terrail, 2010.

PEREIRA, Cláudia Matos. Galeria de Arte Celina: espaço e ideário cultural de uma geração de artistas e intelectuais em Juiz de Fora (1960/1970) Rio de Janeiro, 2015 (Tese doutoramento, UFRJ)

PINTO, Rogério Rezende, Alfredo Ferreira Lage, suas coleções e a constituição do Museu Mariano Procópio - Juiz de Fora, MG. Juiz de Fora, 2008 
(Dissertação, PPG-História, UFJF)

PONTUAL, Roberto. Dicionário das artes plásticas no Brasil. Civilização Brasileira. Rio de Janeiro, 1969.

PRANDI, Reginaldo. "Referências sociais das religiões afro-brasileiras. Sincretismo, branqueamento, africanização". Horizontes antropológicos, vol.4, n.8, Porto Alegre, Jun. 1998., p. 93-111.

ROSA, Rita de Cássia Vianna. As mulheres de "Paraiburgo": representações de gênero em jornais de Juiz de Fora/MG (1964-1975). Niterói, 2009. (Dissertação, Mestrado em História, Universidade Federal Fluminense)

Três amigos pintores. Ana Lúcia Lopes Ribeiro / Djanira de Almeida Diniz / Luiz Vilani. Rio de Janeiro: Editora AMCGuedes, 2012 


\section{Maraliz de Castro Vieira Christo}

Revista de Artes Visuais

v. 24 ก. 42

Doutora pela UNICAMP. Foi bolsista da Foundation Getty junto ao Institut National

nov/dez 2019 d'Histoire de l'Art de Paris. Recebeu o Grande Prêmio Capes de Tese em 2006. Fez estágio pós-doutoral na Universitat Jaume I de Castelló, Espanha, e na

VERSÃO Escuela Nacional de Antropología e Historia-INAH, México. Atualmente é professora Associada da UFJF, pesquisadora do CNPq e FAPEMIG, membro do CBHA. 